NBSIK 84-2863(R)

\title{
Microcomputer-Based Software for Management of Calibration Service
}

U.S. DEPARTMENT OF COMIMERCE

Naticnal Bureal of Standards

National Engineering Laboratory

Center for Electronics and Electrica! Engineering

Electrosystems Division

Washington, DC 20234

Apri! 1984

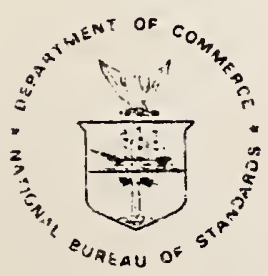

U.S. DEPARTMENT OF SOMNERCE

NATIONAL BUPEAU OF STANDARDS 

NBSIR 84-2863

\section{MICROCOMPUTER-BASED SOFTWARE FOR MANAGEMENT OF CALIBRATION SERVICE}

William E. Anderson

U.S. DEPARTMENT OF COMMERCE

National Bureau of Standards

National Engineering Laboratory

Center for Electronics and Electrical Engineering

Electrosystems Division

Washington, DC 20234

April 1984

U.S. DEPARTMENT OF COMMERCE, Malcolm Baldrige, Secretary NATIONAL BUREAU OF STANDARDS. Emost Amblor. Diroctor 
Abstract.

1. INTRODUCTION.

2. DESCRIPTION OF SOFTWARE

3. SUMMARY

APPENDIX A. . . . . . . . . . . . . . . . . . . . 6

LISTING A. . . . . . . . . . . . . . . . . . 8

DISPLAY A. . . . . . . . . . . . . . . . 10

LISTING B. . . . . . . . . . . . . . . . . . . . 11

DISPLAY B. . . . . . . . . . . . . . . . . . 12

LISTING C. . . . . . . . . . . . . . . . . . . . .13

DISPLAY C. . . . . . . . . . . . . . . . . . 14

LISTING O. . . . . . . . . . . . . . . . . . 15

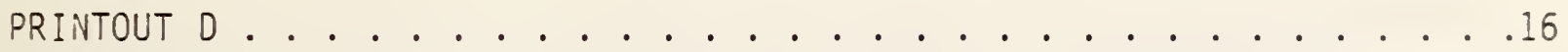

LISTING E. . . . . . . . . . . . . . . . . . . . 17

PRINTOUTE . . . . . . . . . . . . . . . . . . . . . . .

LISTING F. . . . . . . . . . . . . . . . . . . 19

PRINTOUT F . . . . . . . . . . . . . . 20

LISTING G. . . . . . . . . . . . . . . . . . 21

PRINTOUT G. . . . . . . . . . . . . . . . . 22

LISTING H. . . . . . . . . . . . . . . . . . 23

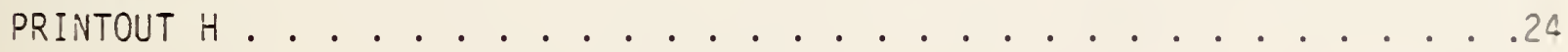

LISTING I. . . . . . . . . . . . . . . . . . 25

PRINTOUT I . . . . . . . . . . . . . . . . . . . . 6

LISTING J. . . . . . . . . . . . . . . . . . . 27

LISTING K. . . . . . . . . . . . . . . . . . 28 

Willian E. Anderson

\section{Abstract}

The majority of the calibration customers' concerns are directed not to the technical details of the calibration service but to the timely delivery of that service. It is therefore proper that the calibration services be closely managed. For a Group or Division with a large calibration load, this can be a difficult task. The Applied Electrical Measurements Group of the Electrosystems Division has developed microcomputer-based software to provide considerable assistance to the calibration manager. With this database software, complete information on the status of all the calibration jobs is instantly available.

Key words: calibration management; calibrations; database management; microcomputer; software

\section{INTRODUCTION}

In order to provide adequate service to calibration clients, good management must be exercised at the Group and/or Division level. Most complaints concerning a calibration service are not directed to the technical aspects of the service but more often to the timely delivery of the service. Therefore, it would be of considerable value if complete information as to the status of each calibration job were instantly accessible.

In the past, the Applied Electrical Measurements Group of the Electrosystems Division kept a calibration log book. The arrival of purchase orders, test folders, and equipment prompted an entry into the log book. Also entered were the device type, closing date and fees. While most of the information necessary to maintain a calibration service was contained in the log, retrieval of the information in real time was not always possible. The requests for additional fiscal and statistical information (e.g., the income per quarter from a specific calibration service), sometimes required excessive amount of time for response.

With the advent of microprocessor-based workstations and commercialiy available database software, vast improvements could be made in providing the information without a significant expenditure in resources. Such a system was developed in the Electrosystems Division and has been in use for the past six months. The system has been able to meet all demands on it and also has served as a means for checking the accuracy of the centralized accounting system. Further, the availability of accurate information on the current financial status of the calibration service permits better planning decisions to be made.

\section{DESCRIPTION OF SOFTWARE}

Relational database software is readily available for both 8 and 16-bit microcomputers. The database management system, dBase II [1], from Ashton-Tate was selected because it was the only such software available at that $t$ ime which 
could be used on all the computers anticipated to be used by the Group. A similar calibration management program could be designed using database management software from other vendors.

While dBase II provides the command structure to create and manipulate databases, the user must provide the programs (in dBase II's language) to tailor the software to the user's needs. (A listing of the various programs along with sample output is provided in the appendix). In order to make it possible for this calibration management software to be used without any knowledge of dBase II, the software was written to be menu-driven. Assuming the operator has turned on the computer, loaded in the operating system, and that the programs and database reside on the default disk drive, entering 'dbase menu' should provide the following onscreen menu:

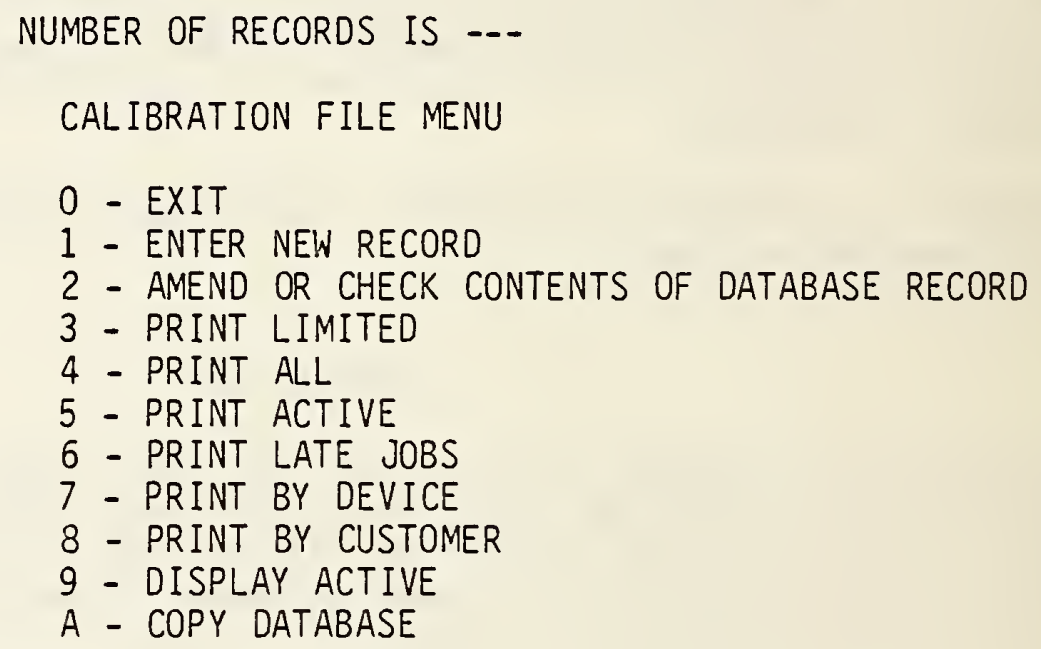

\section{ENTER DESIRED ACTION}

\section{WAITING}

Menu choices ' 1 ' and ' 2 ' provide the user a method for changing the contents of a database record. The program is designed in such a way that each record corresponds to one instrument received for calibration. (For multiple instruments attached to the same test folder, suffixes $A, B, C$, etc. are concatenated to the test number). Each record consists of the following fourteen fields: test number, purchase order number, type of instrument, model name and number, serial number, staff member assigned to calibration, customer's name, customer's city and state (and zip code), starting date for iob, promised date, finishing date, form letter information, number of manhours, and cost (excluding OPMS surcharges). While the contents of most of these fields may be apparent, the intended contents of the form letter information field may need explaining. It is the policy of the Electrosystems Division to keep its customers informed as to the status of their calibration job with the use of form letters. For example, if a purchase order is received with no instrument, the customer is so notified. The customer always receives at least one form letter with the estimated cost of the calibration and the date the job should be finished. The form letter information field is 50 characters wide, permitting the entry of the dates the form letters have been sent out and, if necessary, a one or two letter code describing the form letter contents. The menu choices allow either modification of the database or output of information contained in the database to the user. Each of the choices is explained below. 
0 - EXIT Menu choice ' 0 ' causes the program to terminate and exit to the operating system (DOS or CPM). It is important that the user select this choice before removing the diskettes or turning off the computer as this selection also guarantees that the actual database file is properly updated from memory.

1 - ENTER NEW RECORD Menu choice ' $I$ ' allows the user to enter initial information concerning a calibration job. The user is prompted on each data entry. The day's date is automatically entered as the job start data. In the cases where the test number is not known, a temporary number should be assigned in order to facilitate fast retrieval of the record.

2 - AMEND OR CHECK CONTENTS OF DATABASE RECORD Menu choice ' 2 ' allows the user to observe or update the information in the database as the work progresses. If the user selects menu choice '2', the user will be prompted to give either the test number or purchase order number of the record to be updated or checked. Since the database is indexed on test numbers, a typical search for a test number takes less than 2 seconds.

3 - PRINT LIMITED Menu choice ' 3 ' provides the user a means of getting a partial listing on the system printer of the database contents. The fields printed are the test number, type of instrument, customer name, job closing date, and cost. The total cost or income is also listed. The listing is in order of test numbers.

4 - PRINT ALL Menu choice ' 4 ' results in a more complete listing of the database contents than choice 13.' Specifically all the fields are printed out except the purchase order, staff member, and form letter information fields. The information is printed in compressed print (132 characters per line on the IBM printer). The total cost or income along with the manhours are also listed. Users can get hardcopy access to the three missing fields by exercising choice ' 2 ' and a print screen command if their computer supports it.

5 - PRINT ACTIVE Menu choice '5' permits the user to receive a hardcopy listing of all the active jobs. Basicaliy the database is searched for all records without a closing date entry. This enables the user to check the active jobs against the OPMS monthly statement of active jobs.

6 - PRINT LATE JOBS Menu choice ' 6 ' causes the database to be searched for all records in which the promised date comes before the present date and there is no closing date entry. These jobs demand immediate attention, normally in the form of a letter to the customers informing them of a revised promised date.

7 - PRINT BY DEVICE Menu choice '7' provides the user with a hardcopy summary of all the jobs to date of a particular type of instrument (e.a., voltage transformers). The summary also includes the total income earned for that type of instrument and the calibration manhours expended.

8 - PRINT BY CUSTOMER Menu choice ' 8 ' yields a hardcopy itsting of the jobs done or in progress for a particular customer. The total cost to that customer is also presented. If a customer calls concerning a calibration, this command may be the quickest way to find the correspondina record if the test or purchase order number are not available. 
9 - DISPLAY ACTIVE Menu choice ' 9 ' is identical to choice ' 5 ' except the output is to the display screen and not the printer.

A - COPY DATABASE Menu choice 'A' permits the user to copy the database onto another floppy diskette to serve as backup. It is assumed that the default drive is the "A" drive and contains the database programs and the database. A formatted diskette must be placed in drive "B" before selecting this menu choice. Experience has shown two problems with this menu choice. The first is that the duplication process is relatively slow in $\mathrm{dB}$ ase II. The second is that if an error occurs during the duplication process, one often ends up in the operating system. This could result in the database not being updated since a proper exit from dBase II has not taken place. This command has been left on the display screen as a reminder to the user to backup the database. The best way to do this, however, is exiting via menu choice ' $O$ ' and copying the database file in the operating system, using operating system commands.

The above choices represent only a small fraction of the useful information contained in the database. Unfortunately, the more choices presented on the menu, the more cluttered the screen becomes. A programmer with some familiarity with dBase II can extract a myriad of useful information from the database. For example, if there is a need to know the number and income derived from watthour standards calibrated in the third quarter from state governments, that information can be extracted readily from the database. Also, it is possible to modify the menu choices to better meet the needs of a particular group of users.

The software system described has a great amount of flexibility. If it becomes apparent that additional fields of information need to be saved in the database, they can be added. For example, in the future it may be important to keep track of when and if an instrument has been calibrated by the National Bureau of Standards previously. Also, field sizes can be modified. If it is found that 50 characters do not provide enough space to accommodate the form letter information, the field can be expanded. The information contained in the database can be communicated to files used by word processors or to other computers. The software is portable in the sense that although it was developed on the IBM PC [1], it runs perfectly on the 8-bit storeroom microcomputer after modification of three program lines.

[1] Certain commercial hardware and software are identified in this report in order to specify the procedure used to manage the calibration data. Such identification does not imply recommendation or endorsement by the National Bureau of Standards nor does it imply that the items identified are necessarily the best available for the purpose. 
We have developed a microcomputer-based software system for the management of a calibration service at the Group or Division level. The system has been designed for user "friendliness." A Group secretary has demonstrated total success in using the software. The software has provided Group and Division management with information on the status of calibrations far superior to that currently available from other sources. It has allowed the Group to make better estimates of the financial status concerning our calibration services. In fact, it is a likely case that this software itself has justified the investments the Group has made in the procurement of the microprocessor workstations. 


\section{APPENDIX A}

The microcomputer-based software for the management of a calibration service is presented. The software was written to be used on an IBM PC or XT using dBase II version 2.4. A slight modification will be presented that enables the software to be run on the 8-bit storeroom microcomputer. Comments are not encouraged in dBase II in the sense that they must be on a separate program line. Variable names have been chosen, however, that should help in understanding the programs.

Listing $A$ is the program entitled 'menu.' It can be run from the operating system by typing 'dbase menu' or from dBase II by typing 'do menu.' This program causes the menu shown in display A to appear on the screen. Users not having a color monitor and users of the 8-bit storeroom microcomputer should delete the second line (SET COLOR TO 4.2). The database in this listing has the file name CALFY83. The software is designed so that a new database should be used each fiscal year.

Selection of menu choice ' 1 ' causes the program 'NEWRCD' (1isting B) to be called. Display B shows the resulting screen display. The user is prompted for each of the possible fields of data entry.

Selection of menu choice ' 2 ' calls the program 'AMERCD' (1isting C). The user is requested to enter either the test number or purchase order number so the software can find the record to be modified or checked. The resulting display is shown in display $C$.

Selection of menu choice ' 3 ' calls the program 'PRINTLIM' (1isting $D$ ). This listing also includes the report format to be used for the printout. ( $M=1$ sets the lefthand margin, $N$ results in no page heading, $N$ results in a single-spaced report, $Y$ allows numerical totalling, and $N$ disallows subtotalling). A page of the resulting printout is shown in printout $D$.

Selection of menu choice ' 4 ' calls the program 'PRINTALL' (1isting E). The second line of the program tells the IBM printer to use compressed type. For the Prism printer used with the storeroom microcomputer, this line should be changed from 'chr(15)' to 'chr(31).' A page of the resulting printout is shown in printout $E$.

Selection of menu choice ' 5 ' calls the program 'PRINTACT' (listing F). A sample of the printout is shown in printout $F$.

Selection of menu choice ' 6 ' calls the program 'PRINTDEL' (1isting G). A sample of the printout is shown in printout $G$.

Selection of menu choice ' 7 ' calls the program 'PRINTDEV' ( 1 isting $H$ ). The user is prompted to enter the type of calibration instrument. A sample of the printout is shown in printout $H$.

Selection of menu choice ' 7 ' calls for the program 'PRINTCUS' (1isting I). The user is prompted to enter the customer's name. The second line of the program tells the IBM printer to use compressed type. For the Prism printer used with the storeroom microcomputer, this line should be changed from 'chr(15)' to 'chr(31).' A sample of the printout is shown in printout I. 
Selection of menu choice ' 9 ' calls the program 'OISPACT' (listing J). This menu choice is identical to choice ' 5 ' except the output is to the screen and not the printer. The report format for this program 'PRINTACT' is shown in listing $F$. Selection of menu choice 'A' calls the program 'DUP' (listing K). As mentioned in the main text, this command should only be used on a machine known to have two well-running disk drives. 
MENU

SET COLOR TO 4,2

ERASE

DO WHILE TRUE

USE CALFY83

GO BOTTOM

ERASE

?

?

USE

NUMBER OF RECORDS IS', \#

USE CALFY83 INDEX TESTNO

?

?'

?

? I

? 1

? 1

DATABASE RECORD'

?

?

? 1

? '

? 1

?'

? 1

?'

?

? 1

WAIT TO ACTION

DO CASE

CASE ACTION=' 0 '

SET TALK ON QUIT

CASE ACTION='1'

DO NEWRCD

CASE ACTION=' 2 '

DO AMERCD

CASE ACTION $=13$ '

DO PRINTLIM

CASE ACTION=' 4 '

DO PRINTALL

CASE ACTION='5'

DO PRINTACT

CASE ACTION $=$ ' 6 '

DO PRINTDEL

CASE ACTION $=17^{\prime}$

DO PRINTDEV

CASE ACTION=' 8 '

DO PRINTCUS

CASE ACTION=' 9 '

DO DISPACT

\section{CALIBRATION FILE MENU'}

0 - EXIT'

1 - ENTER NEW RECORD'

2 - AMEND OR CHECK CONTENTS OF

3 - PRINT LIMITED'

4 - PRINT ALL'

5 - PRINT ACTIVE'

6 - PRINT LATE JOBS'

7 - PRINT BY DEVICE'

8 - PRINT BY CUSTOMER'

9 - DISPLAY ACTIVE'

A - COPY DATABASE'

ENTERED DESIRED ACTION ' 
CASE ACTION $=$ ' $A$ '

DO DUP

OTHERWISE

? ' INVALID ENTRY, RE-ENTER'

ENDCASE

ENDDO

RETURN 
DISPLAY A

NUMBER OF RECORDS IS 169

CALIBRATION FILE MENU

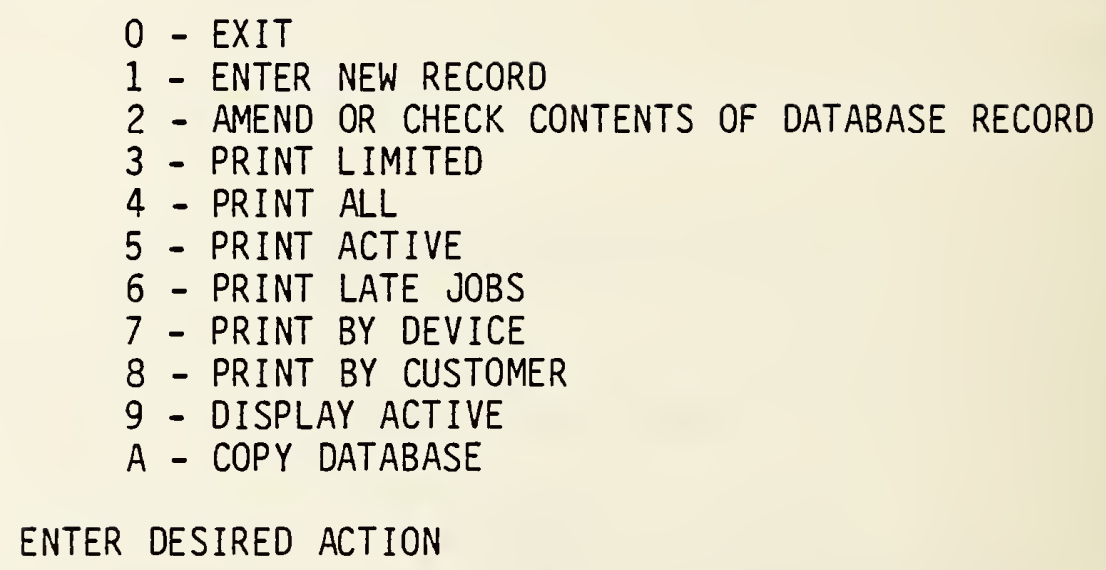

ENTER DESIRED ACTION

WAITING 


\section{NEWRCD}

ERASE

GO BOTTOM

STORE ' $Y$ ' TO $X$

DO WHILE $X=' Y$ '

ERASE

STORE DATE() TO M:DATESTAR

STORE $10 / /$ ' TO M:DATEPROM

STORE $1 / /$ ' TO M:DATECLOS

STORE ' 1 TO M:TEST:NO

STORE

STORE

STORE

STORE

STORE

STORE

STORE

$$
\begin{aligned}
& \text { 1 TO M:MODEL } \\
& \text { - TO M:CUSTNAM } \\
& \text { - TO M:STAFF }
\end{aligned}
$$

TO M:FORMLET

STORE 0 TO M:MANHOURS

STORE 0 TO M:COST

O 2,0 SAY "TODAY'S DATE" GET M:DATESTAR PICTURE ' $99 / 99 / 99$ '

(a 3,0 SAY 'TEST NUMBER' GET M:TEST:NO

a 3,0 SAY 'PURCHASE ORDER NUMBER' GET M:PO:NO

d 5,0 SAY 'TYPE CHOICES ARE; MAP, WATTHOUR STANDARD, CURRENT TRANSFORMER, '

a 6,0 SAY 'VOLTAGE TRANSFORMER,DC DIVIDER, AC DIVIDER, XRAY DIVIDER, DC \& AC'

(a 7,0 SAY 'DIVIDER, IMPULSE DIVIDER, VT COMPARATOR,OR CT COMPARATOR' GET M:TYPE

(d 8,0 SAY 'INSTRUMENT MODEL' GET M:MODEL

a 9,0 SAY 'INSTRUMENT SERIAL NUMBER' GET M:SERIALNO

a 10,0 SAY 'CUSTOMER NAME' GET M:CUSTNAM

a 11,0 SAY 'CUSTOMER LOCATION' GET M:LOCATION

a 12,0 SAY 'CALIBRATION STAFF MEMBER' GET M:STAFF

a 13,0 SAY 'DATE PROMISED' GET M:DATEPROM PICTURE ' $99 / 99 / 99$ '

a 14,0 SAY 'FORM LETTER INFO' GET M:FORMLET

a 15,0 SAY 'CLOSING DATE' GET M:DATECLOS PICTURE ' $99 / 99 / 99$ '

a 16,0 SAY 'COST EXCLUDING OMS SURCHARGE' GET M:COST PICTURE $1 \# \# \# \# \# \# . \# \# 1$

a 17,0 SAY 'CALIBRATION MANHOURS' GET M:MANHOURS PICTURE '\#\#\#\#.\#'

READ

APPEND BLANK

REPLACE TEST:NO WITH M:TEST:NO, TYPE WITH !(M:TYPE), MODEL 'NITH !(M:MODEL)

REPLACE SERIALNO WITH ! (M:SERIALNO), STAFF WITH ! (M:STAFF)

REPLACE LOCATION WITH !(M:LOCATION), DATESTAR WITH M:DATESTAR

REPLACE FORMLET WITH ! (M:FORMLET), DATECLOS WITH M:DATECLOS

REPLACE COST WITH M:COST, MANHOURS WITH M:MANHOURS, DATEPROM WITH M:DATEPROM

REPLACE PO:NO WITH ! (M:PO:NO), CUSTNAM WITH !(M:CUSTNAM)

ACCEPT 'WANT TO CONTINUE ' $Y$ ' OR ' $N$ '" TO $X I$

STORE ! $(X 1)$ TO $X$

ENDDO

RETURN 
DISPLAY B

TODAY'S DATE; 12/15/83:

TEST NUMBER:

PURCHASE ORDER NUMBER:

TYPE CHOICES ARE: MAP, WATTHOUR STANDARD, CURRENT TRANSFORMER, CAPACITOR, VOLTAGE TRANSFORMER,DC DIVIDER, AC DIVIDER, XRAY DIVIDER, DC \& AC

DIVIDER, IMPULSE DIVIDER, VT COMPARATOR,OR CT COMPARATOR:

INSTRUMENT MODEL:

INSTRUMENT SERIAL NUMBER:

CUSTOMER NAME :

CUSTOMER LOCATION:

CALIBRATION STAFF MEMBER:

DATE PROMISED:0 / / :

FORM LETER INFO:

CLOSING DATE: / / :

COST EXCLUDING OMS SURCHARGE: 0.00 :

CALIBRATION MANHOURS: 0.00 : 
AMERCD

STORE ' $Y$ ' TO $X$

DO WHILE $X=' Y$ '

ERASE

STORE

1 TO M:TEST:NO

- TO M:PO:NO

STORE

ACCEPT "ENTER TEST NUMBER IF KNOWN OTHERWISE 'RETURN'" TO M:TEST:NO

IF $M: T E S T: N O=1$

ACCEPT "ENTER PURCHASE ORDER NUMBER IF KNOWN OTHERWISE 'RETURN'" TO M:PO:NO

IF $M: P O: N O=1$ '

RETURN

ELSE

LOCATE FOR !(M:PO:NO) \$ PO:NO

ENDIF

ELSE

FIND \&M:TEST:NO

ENDIF

IF (.NOT. EOF) .AND. $(\#<>0)$

a 5,0 SAY 'TEST NUMBER' GET TEST:NO

a 6,0 SAY 'PURCHASE ORDER NUMBER' GET PO:NO

a 7,0 SAY 'TYPE' GET TYPE

a 8,0 SAY 'INSTRUMENT MODEL' GET MODEL

(2 9,0 SAY 'SERIAL NUMBER' GET SERIALNO

a 10,0 SAY 'CUSTOMER NAME' GET CUSTNAM

a 11,0 SAY 'CUSTOMER LOCATION' GET LOCATION

a 12,0 SAY 'JOB START DATE' GET DATESTAR PICTURE ' $99 / 99 / 99$ '

(a 13,0 SAY 'DATE PROMISED' GET DATEPROM PICTURE ' $99 / 99 / 99$ '

(a 14,0 SAY 'FORM LETTER INFO' GET FORMLET

a 15,0 SAY 'STAFF NAME' GET STAFF

a 16,0 SAY 'CLOSING DATE' GET DATECLOS PICUTURE ' $99 / 99 / 99$ '

a 17,0 SAY 'COST' GET COST PICTURE '\#\#\#\#\#\#.\#\#'

(a) 18,0 SAY 'MANHOURS' GET MANHOURS PICTURE '\#\#\#\#\#.\#\#'

a 19,0

(a) 20,0

ACCEPT "WANT TO MAKE CHANGES ' $Y$ ' OR ' $N$ '" TO $Y 1$

STORE ! $Y 1)$ TO $Y$

IF $Y=' Y$ '

READ

ENDIF

ELSE

(a 21,0 SAY 'RECORD COULD NOT BE FOUND'

ENDIF

ACCEPT "WANT TO CHANGE OR OBSERVE ANOTHER RECORD ' $Y$ ' OR 'N $N$ '" TO $X 1$

STORE ! $(X 1)$ TO X

ENDDO

RETURN 
DISPLAY C

ENTER TEST NUMBER IF KNOWN OTHERWISE 'RETURN':228554

TEST NUMBER: 228554 :

PURCHASE ORDER NUMBER:

TYPE:WATTHOUR STANDARD

INSTRUMENT MODEL: SCIENTIFIC COLUMBUS SC-60:

SERIAL NUMBER:

CUSTOMER NAME:RFL INDUSTRIES

CUSTOMER LOCATION:BOONTON, NJ 07005

JOB START DATE: / / :

DATE PROMISED: $10 / 01 / 82$ :

FORM LETTER INFO:

STAFF NAME:RAMBOZ

CLOSING DATE: $10 / 01 / 82$ :

COST: 262.50:

MANHOURS: 0.00 :

WANT TO MAKE CHANGES ' $Y$ ' OR ' $N$ ': 


\section{PRINTL IM}

REPORT FORM PRINTLIM TO PRINT RETURN

\section{PRINTLIM.FRM}

$$
\begin{aligned}
& M=1 \\
& N \\
& N \\
& Y \\
& N \\
& 7, \text { TEST:NO } \\
& 20, \text { TYPE } \\
& 30, \text { CUSTNAM } \\
& 8, \text { DATECLOS } \\
& 9, \text { COST } \\
& Y
\end{aligned}
$$


PAGE NO. 00002

$12 / 15 / 83$

229944 CURRENT TRANSFORMER

229948 WATTHOUR STANDARD

230019 MAP

230025 DC DIVIDER

230121A VOLTAGE TRANSFORMER

230121B VOLTAGE TRANSFORMER

230121C VOLTAGE TRANSFORMER

2301210 VOLTAGE TRANSFORMER

$230121 E$ VOLTAGE TRANSFORMER

$230121 \mathrm{~F}$ VOLTAGE TRANSFORMER

230121G WATTHOUR STANDARD

230176 WATTHOUR STANDARD

230180 WATTHOUR STANDARD

230181 WATTHOUR STANDARD

230182 WATTHOUR STANDARD

230188 WATTHOUR STANDARD

230193 WATTHOUR STANDARD

230198 WATTHOUR STANDARD

230207 DC DIVIDER

230219 WATTHOUR STANDARD

230238 MAP

230241 WATTHOUR STANDARD

230254 WATTHOUR STANDARD

230261 CURRENT TRANSFORMER

230268 WATTHOUR STANDARD

230280 CURRENT TRANSFORMER

230285A WATTHOUR STANDARD

230285B WATTHOUR STANDARD

230285C WATTHOUR STANDARD

230308 WATTHOUR STANDARD

230345A WATTHOUR STANDARD

230345B WATTHOUR STANDARD

230435 DC DIVIDER

230455A VT COMPARATOR

2304558 VOLTAGE TRANSFORMER

230471 VOLTAGE TRANSFORMER

230493A VOLTAGE TRANSFORMER

230493B CAPACITOR

230493C CAPACITOR

230493D CAPACITOR

230497 WATTHOUR STANDARD

230506 WATTHOUR STANDARD

230523 WATTHOUR STANDARD

230530A WATTHOUR STANDARD

$230530 B$ WATTHOUR STANDARD

230530C WATTHOUR STANDARD

230538 WATTHOUR STANDARD

230584 WATTHOUR STANDARD

230589 WATTHOUR STANDARD

230640 XRAY DIVIDER
LOCKHEED GEORGIA COMPANY

RFL INDUSTRIES

WEST TEXAS UTILITIES CO

GENERAL ELECTRIC

MILL-POWER SUPPLY COMPANY

MILL-POWER SUPPLY COMPANY

MILL-POWER SUPPLY

MILL-POWER SUPPLY

MILL-POWER SUPPLY

MILL-POWER SUPPLY

MILL-POWER SUPPLY

DALLAS POWER \& LIGHT

STATE OF MARYLAND

PHILADELPHIA ELECTRIC

RFL INDUSTRIES

TEXAS POWER \& LIGHT

CENTRAL POWER \& LIGHT

UNION ELECTRIC

SANDIA NATIONAL LABORATORIES

GENERAL ELECTRIC COMPANY

SOUTH CAROLINA ELECTRIC \& GAS

TRANSDATA

KOREAN STANDARDS RESEARCH INST

RAYTHEON

THE UNIV. OF WISCONSIN-MADISON

AVCO SYSTEMS DIVISION

GULF POWER

GULF POWER

GULF POWER

GENERAL ELECTRIC COMPANY

PUBLIC SERVICE ELECTRIC \& GAS

PUBLIC SERVICE ELECTRIC \& GAS

GENERAL ELECTRIC COMPANY

PACIFIC GAS \& ELECTRIC

PACIFIC GAS \& ELECTRIC

BOEING AEROSPACE COMPANY

GENERAL ELECTRIC COMPANY

GENERAL ELECTRIC COMPANY

GENERAL ELECTRIC COMPANY

GENERAL ELECTRIC COMPANY

HOUSTON LIGHTING \& POWER

SCIENTIFIC COLUMBUS

VIRGINIA ELECTRIC \& POWER

GENERAL ELECTRIC COMPANY

GENERAL ELECTRIC COMPANY

GENERAL ELECTRIC COMPANY

GENERAL ELECTRIC COMPANY

CORN BELT POWER CORP.

MCDONNELL DOUGLAS ASTRONAUTICS

TECHNICARE CORPORATION
$05 / 10 / 83$

$03 / 25 / 83$

$04 / 15 / 83$

$03 / 11 / 83$

$03 / 25 / 83$

$03 / 25 / 83$

$03 / 01 / 83$

$03 / 01 / 83$

$03 / 01 / 83$

$03 / 01 / 83$

$03 / 01 / 83$

$02 / 01 / 83$

$02 / 01 / 83$

$02 / 01 / 83$

$03 / 01 / 83$

$03 / 01 / 83$

$03 / 01 / 83$

$03 / 01 / 83$

$03 / 01 / 83$

$03 / 01 / 83$

$03 / 01 / 83$

$03 / 01 / 83$

$03 / 01 / 83$

$03 / 01 / 83$

$03 / 01 / 83$

$03 / 01 / 83$

$03 / 01 / 83$

$03 / 01 / 83$

$03 / 01 / 83$

$03 / 01 / 83$

$04 / 01 / 83$

$04 / 01 / 83$

$04 / 01 / 83$

$04 / 01 / 83$

$04 / 01 / 83$

$04 / 01 / 83$

$04 / 01 / 83$

$04 / 01 / 83$

$04 / 01 / 83$

$04 / 01 / 83$

$04 / 01 / 83$

$04 / 01 / 83$

$04 / 01 / 83$

$05 / 01 / 83$

$05 / 01 / 83$

$05 / 01 / 83$

$05 / 01 / 83$

$05 / 01 / 83$

$05 / 01 / 83$

$05 / 01 / 83$
645.00

1016.00

485.00

530.00

3879.00

0.00

0.00

0.00

0.00

0.00

1250.00

412.00

508.00

781.00

898.00

412.00

485.00

664.00

530.00

1288.00

641.00

1055.00

508.00

785.00

485.00

704.00

2090.00

0.00

0.00

586.00

984.00

0.00

430.00

772.00

1799.00

851.00

1578.00

760.00

0.00

0.00

1343.00

820.00

430.00

3925.00

0.00

0.00

742.00

549.00

634.00

630.00 


\section{PRINTALL}

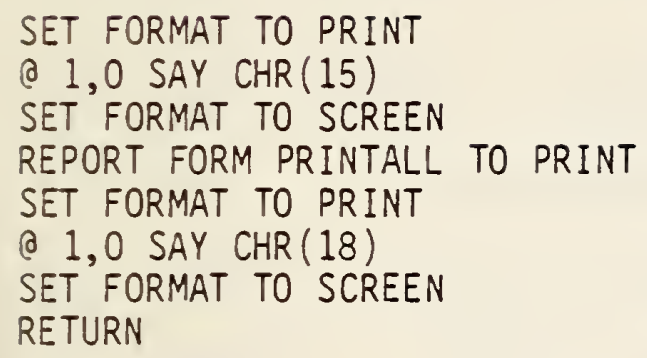

$$
7,
$$

11, TYPE

10, SERIALNO

15, MODEL

15 , CUSTNAM

15, LOCATION

8 , DATESTAR START

8,DATEPROM

PROMISED

8 ,DATECLOS

CLOSED

9, COST

Y

8 , MANHOURS 
FAGE MQP. 0000?

$: 2 / 12 / 83$

BTHลT FROMIGE CLIEE

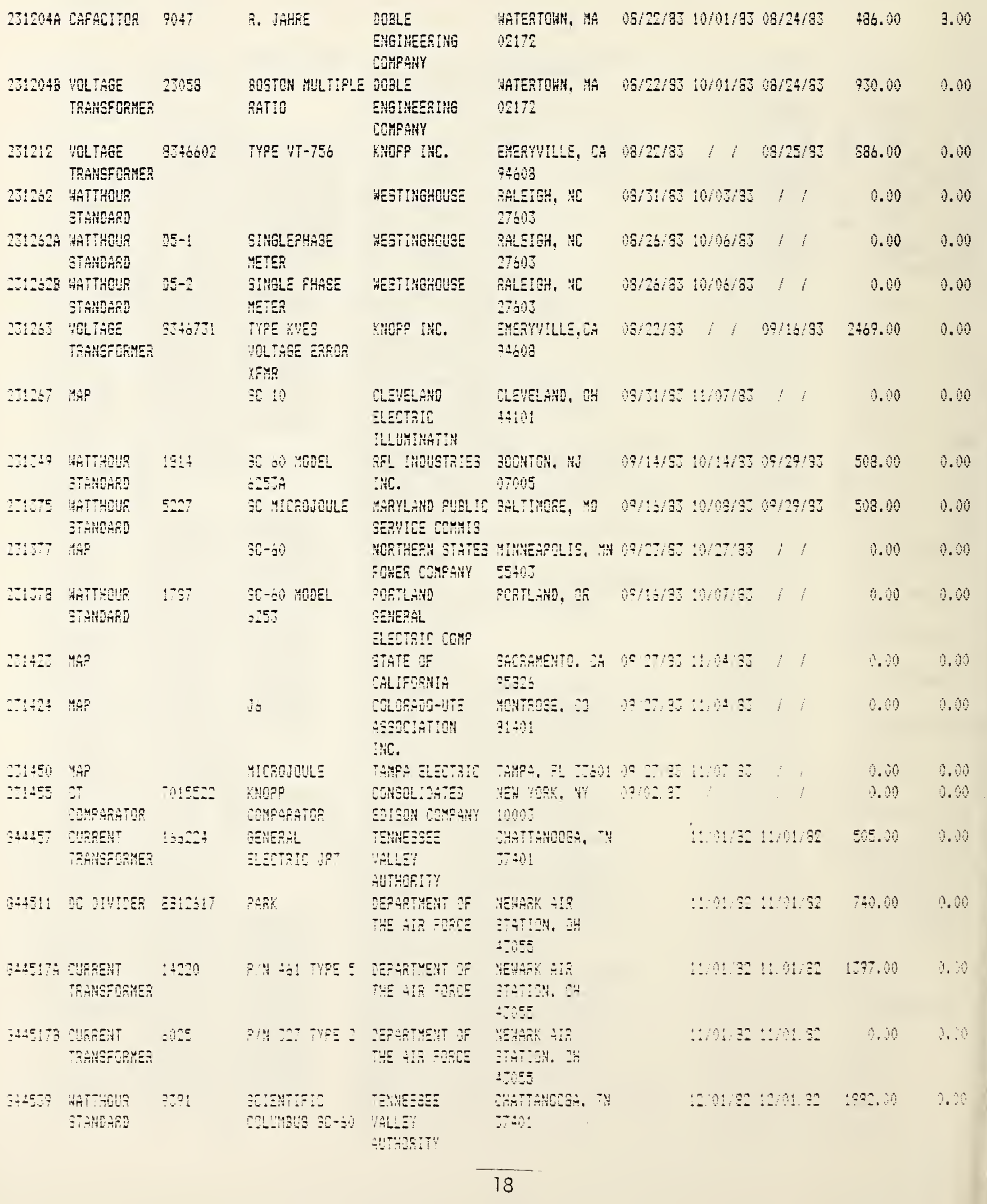


LISTING $F$

PRINTACT

REPORT FORM PRINTACT FOR DATECLOS=" "TO PRINT RETURN

\section{PRINTACT.FRM}

$M=1$

Y

ACTIVE JOBS

$\mathrm{N}$

N

7, TEST:NO

20, TYPE

30 , CUSTNAM

8, DATESTAR

START

8,DATEPROM

PROMISED 
PRINTOUT $F$

PAGE NO. 00001

$12 / 15 / 83$

ACTIVE JOBS

START PROMISED

0000001 XRAY DIVIDER

KIETHLEY CORP.

$09 / 28 / 83$

0000002 CURRENT TRANSFORMER

PHILADELPHIA ELECTRIC COMPANY

$09 / 12 / 83$

0000003

CURRENT TRANSFORMER

0000006 MAP

230988

CURRENT TRANSFORMER

231096

WATTHOUR STANDARD

PHILADELPHIA ELECTRIC COMPANY

$09 / 12 / 83$

UNIVERSITY OF WISCONSIN

$09 / 27 / 83$

KNOPP INC.

$06 / 16 / 83$

SCIENTIFIC COLUMBUS

$00 / 00 / 00$

$00 / 00 / 83$

CURRENT TRANSFORMER

231200 CURRENT TRANSFORMER

231262

$231262 \mathrm{~A}$ WATTHOUR STANDARD

GENERAL ELECTRIC COMPANY

$08 / 12 / 83$

$08 / 31 / 83$

WATTHOUR STANDARD

WESTINGHOUSE

$08 / 26 / 83$

WESTINGHOUSE

$08 / 26 / 83$

231262B WATTHOUR STANDARD

231267 MAP

231377 MAP

231378 WATTHOUR STANDARD

231423 MAP

231424 MAP

231450 MAP

231455

G44691

CT COMPARATOR

MAP

G44700A

VOLTAGE TRANSFORMER

G44700B

VOLTAGE TRANSFORMER

WEST INGHOUSE

$08 / 31 / 83$

PORTLAND GENERAL ELECTRIC COMP 09/16/83

STATE OF CALIFORNIA

$09 / 27 / 83$

COLORADO-UTE ASSOCIATION INC. 09/27/83

TAMPA ELECTRIC

$09 / 27 / 83$

CONSOLIDATED EDISON COMPANY

$09 / 02 / 83$

BONNEVILLE POWER ADMINISTRATIO 09/02/83

NAVAL AIR REWORK FACILITY

$09 / 12 / 83$

NAVAL AIR REWORK FACILITY

$09 / 12 / 83$

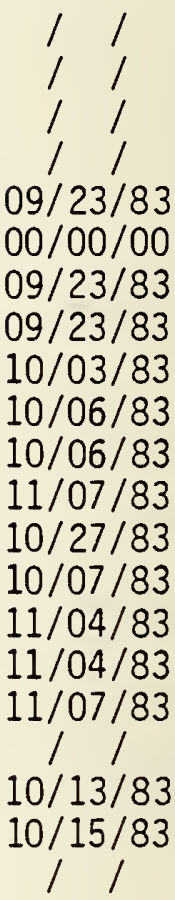




\section{PRINTDEL}

\section{ERASE}

STORE DATE() TO M:DATESTAR

REPORT FORM PRINTDEL FOR ( ( ( (M:DATESTAR > DATEPROM $). O R$. ;

$\$(M:$ DATESTAR , 7,2) $>\$($ DATEPROM , 7, 2)) .AND.

DATECLOS $=1$ ') .AND. DATEPROM $\langle 1 / / l$ ') .AND.;

DATEPROM $〉 10 / / 1)$ TO PRINT

RETURN

PRINTDEL.FRM

$M=1$

Y

LATE JOBS

$\mathrm{N}$

$\mathrm{N}$

7, TEST: NO

10, STAFF

20, TYPE

30 , CUSTNAM

8, DATEPROM 
PRINTOUT G

PAGE NO. 00001

$12 / 15 / 83$

LATE JOBS

230988 RAMBOZ CURRENT TRANSFORMER KNOPP

$09 / 23 / 83$

231096 RAMBOZ WATTHOUR STANDARD SCIENTIFIC COLUMBUS 00/00/00

231190 RAMBOZ CURRENT TRANSFORMER GENERAL ELECTRIC COMPANY 09/23/83

231200 RAMBOZ CURRENT TRANSFORMER YOKOGAWA CORP. 09/23/83

231262 RAMBOZ WATTHOUR STANDARD WESTINGHOUSE 10/03/83

231262A RAMBOZ WATTHOUR STANDARD WESTINGHOUSE 10/06/83

231262B RAMBOZ WATTHOUR STANDARD WESTINGHOUSE 10/06/83

231267 RAMBOZ MAP CLEVELAND ELECTRIC ILLUMINATIN 11/07/83

231377 RAMBOZ MAP NORTHERN STATES POWER COMPANY 10/27/83

231378 RAMBOZ WATTHOUR STANDARD PORTLAND GENERAL ELECTRIC COMP 10/07/83

231423 RAMBOZ MAP STATE OF CALIFORNIA 11/04/83

231424 RAMBOZ MAP COLORADO-UTE ASSOCIATION INC. 11/07/83

231450 RAMBOZ MAP TAMPA ELECTRIC 11/07/83

G44691 RAMBOZ MAP BONNEVILLE POWER ADMINISTRATIO $10 / 13 / 83$

G44700A ANDERSON VOLTAGE TRANSFORMER NAVAL AIR REWORK FACILITY 10/15/83 
PRINTDEV

STORE ' $Y$ ' TO $X$

DO WHILE $X=' Y$ '

ERASE

STORE '

a 1,0 SAY 'DEVICE TYPE' GET M:TYPE

READ

SET HEADING TO \&M:TYPE

REPORT FORM PRINTDEV FOR ! (M:TYPE)=TYPE TO PRINT

SET HEADING TO

ACCEPT "PRINTOUT FOR OTHER DEVICES ' $Y$ ' OR ' $N$ '" TO $X I$

STORE ! $\times 1)$ TO $X$

ENDDO

RETURN

PRINTDEV.FRM

$M=1$

N

N

Y

N

7, TEST : NO

15 , MODEL

15 , CUSTNAM

15, LOCATION

$9, \operatorname{COST}$

$Y$

8,MANHOURS

Y 
PRINTOUT H

PAGE NO. 00001 DC DIVIDER

$12 / 15 / 83$

\begin{tabular}{|c|c|c|c|c|c|}
\hline 229529 & PARK & $\begin{array}{l}\text { BIDDLE } \\
\text { INSTRUMENTS }\end{array}$ & $\begin{array}{l}\text { BLUE BELL, PA } \\
19422\end{array}$ & 430.00 & 0.00 \\
\hline 229923 & PARK & $\begin{array}{l}\text { ROCKWELL } \\
\text { INTERNATIONAL }\end{array}$ & DOWNEY, CA & 430.00 & 0.00 \\
\hline 230025 & $\begin{array}{l}\text { FLUKE MODEL } \\
80 E-10\end{array}$ & $\begin{array}{l}\text { GENERAL } \\
\text { ELECTRIC }\end{array}$ & $\begin{array}{l}\text { KING OF } \\
\text { PRUSSIA, PA } \\
19406\end{array}$ & 530.00 & 0.00 \\
\hline 230207 & PARK & $\begin{array}{l}\text { SANDIA NATIONAL } \\
\text { LABORATORIES }\end{array}$ & $\begin{array}{l}\text { ALBUQUERQUE, NM } \\
87185\end{array}$ & 530.00 & 0.00 \\
\hline 230435 & $\begin{array}{l}\text { SINGER MODEL } \\
\text { PARK }\end{array}$ & $\begin{array}{l}\text { GENERAL } \\
\text { ELECTRIC } \\
\text { COMPANY }\end{array}$ & $\begin{array}{l}\text { CHAMBLEE, GA } \\
30341\end{array}$ & 430.00 & 0.00 \\
\hline 230751 & HALLMARK & $\begin{array}{l}\text { WESTINGHOUSE } \\
\text { ELECTRIC }\end{array}$ & $\begin{array}{l}\text { BALTIMORE, MD } \\
21203\end{array}$ & 430.00 & 0.00 \\
\hline 230771 & $\begin{array}{l}\text { HALLMARK MODEL } \\
\text { PARK }\end{array}$ & $\begin{array}{l}\text { BENDIX } \\
\text { CORPORATION }\end{array}$ & $\begin{array}{l}\text { SIDNEY, NY } \\
13838\end{array}$ & 430.00 & 0.00 \\
\hline 230858 & HALLMARK & $\begin{array}{l}\text { GENERAL } \\
\text { DYNAMICS }\end{array}$ & $\begin{array}{l}\text { FORT WORTH, TX } \\
76101\end{array}$ & 430.00 & 0.00 \\
\hline 230905 & & $\begin{array}{l}\text { MCDONNELL } \\
\text { DOUGLAS }\end{array}$ & $\begin{array}{l}\text { ST. LOUIS, MO } \\
63166\end{array}$ & 840.00 & 0.00 \\
\hline 230929 & $\begin{array}{l}\text { ROSS MODEL } \\
\text { VD240-6.2-J-K-D } \\
M\end{array}$ & $\begin{array}{l}\text { ROSS } \\
\text { ENG INEER ING }\end{array}$ & $\begin{array}{l}\text { CAMPBELL, CA } \\
95008\end{array}$ & 430.00 & 0.00 \\
\hline 230947 & HALLMARK & $\begin{array}{l}\text { RAYTHEON } \\
\text { COMPANY }\end{array}$ & $\begin{array}{l}\text { ANDOVER, MA } \\
01810\end{array}$ & 430.00 & 0.00 \\
\hline G44511 & PARK & $\begin{array}{l}\text { DEPARTMENT OF } \\
\text { THE AIR FORCE }\end{array}$ & $\begin{array}{l}\text { NEWARK AIR } \\
\text { STATION, OH } \\
43055\end{array}$ & 740.00 & 0.00 \\
\hline G44568 & SIEFERT & $\begin{array}{l}\text { NAT IONAL BUREAU } \\
\text { OF STANDARDS }\end{array}$ & $\begin{array}{l}\text { WASH INGTON, DC } \\
20234\end{array}$ & 430.00 & 0.00 \\
\hline G44660 & HALLMARK PVD & $\begin{array}{l}\text { DEPARTMENT OF } \\
\text { THE ARMY }\end{array}$ & $\begin{array}{l}\text { FT. MONMOUTH, } \\
\text { NJ } 07703\end{array}$ & 430.00 & 0.00 \\
\hline * TOTA & & & & 6940.00 & 0.00 \\
\hline
\end{tabular}




\section{PRINTCUS}

\section{ERASE}

SET FORMAT TO PRINT

(a) 1,0 SAY CHR (15)

SET FORMAT TO SCREEN

ACCEPT 'CUSTOMER NAME' TO CUST-

SET HEADING TO \&CUST

REPORT FORM PRINTCUS FOR !(CUST) $=\$$ (CUSTNAM, 1, LEN(CUST)) TO

PRINT

SET HEADING TO

SET FORMAT TO PRINT

(a) 1,0 SAY CHR (18)

SET FORMAT TO SCREEN

RETURN

PRINTCUS.FRM

$M=1, W=132$

$\mathrm{N}$

$\mathrm{N}$

Y

N

7, TEST : NO

20 , TYPE

15 , MODEL

30, LOCATION

10, STAFF

8, DATEPROM

PROMISED

9, COST

Y 


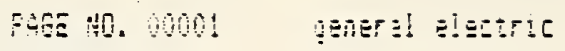

12.15:35

FOHISEN

230025 is DHPDE

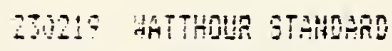

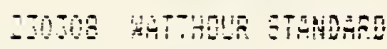

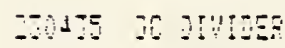

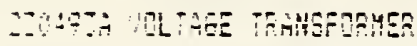

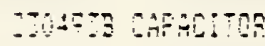

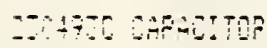

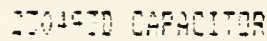

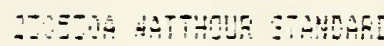

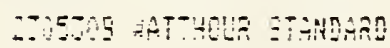

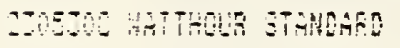

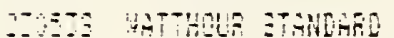

-2:ation

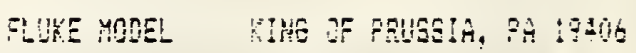
BoE-10

GEEEAL BLETAIC :T-10

GyEAT

BE:TAL T'PE

$15-10$

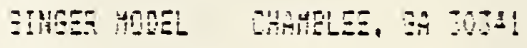
?)तk

GEYERL

ELETAIC

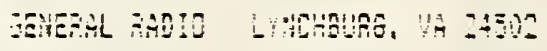

$14: 4$

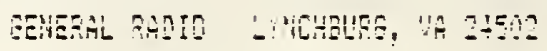

$\vdots \div \div 4$

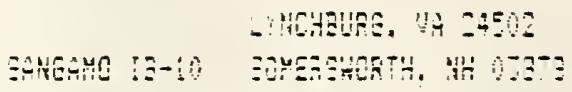

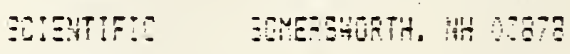

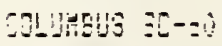

SESTIF:

colusys ge-2is

OE:BTTE:

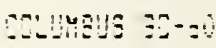

WETH $=2$

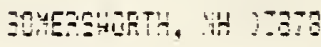

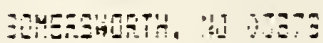

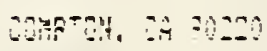

HISAETH 0410183

530.00

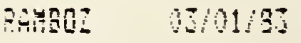

1980.60

74noz 0010195 586.00

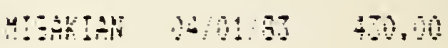

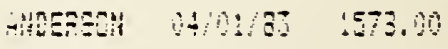

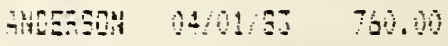

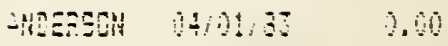

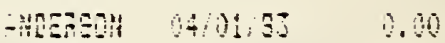

=

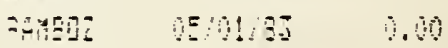

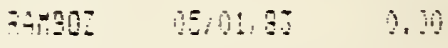

=ำ

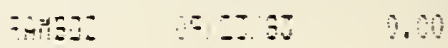

$=97.9$ 
LISTING $J$

\section{DISPACT}

REPORT FORM PRINTACT FOR DATECLOS=" "

$?$

? ' HIT RETURN FOR MENU'

WAIT TO CHOICE

RETURN 
LISTING K

DUP

COPY TO B:CALFY83

RETURN 
NBS.114A $9 E V .-2.8 C$

\begin{tabular}{|c|c|c|}
\hline $\begin{array}{l}\text { U.S. SEDT. O= COMM. } \\
\text { BIBLIOGRAPHIC DATA } \\
\text { SHEET SEe ins:uctionsi }\end{array}$ & $\begin{array}{l}\text { R. PUSLICATION OR } \\
\text { REPORT NO. } \\
\text { NBSIR } 84-2863\end{array}$ & $\begin{array}{r}\text { 2. Performing Organ. Report Nof 3. Puolication Date } \\
\text { April } 1984\end{array}$ \\
\hline \multicolumn{3}{|c|}{$\begin{array}{l}\text { MICROCOMPUTER-BASED SOFTWARE FOR } \\
\text { YANAGEMENT OF CALIBRATION SERVICE }\end{array}$} \\
\hline \multicolumn{3}{|c|}{ 5. AUTHOR(S) } \\
\hline \multicolumn{2}{|c|}{ 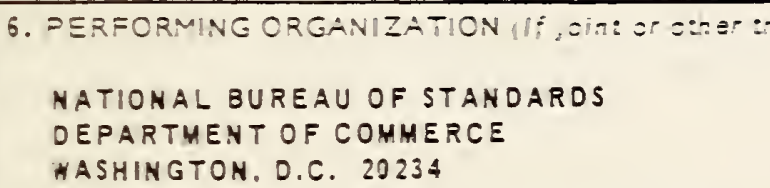 } & $\begin{array}{l}\text { 7. ConiracelGrans No. } \\
\text { 8. Type of Repor: } 3 \text { Perios Coveres }\end{array}$ \\
\hline \multicolumn{3}{|c|}{ 9. SPONSORING ORGANIZATICN NANEANO CONPIETEADORESS (SIrA:, CI:Y, S:E:A, ZIF) } \\
\hline \multicolumn{3}{|c|}{ 10. SUPPLENENTARY NOTES } \\
\hline
\end{tabular}

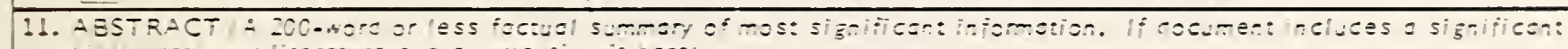
ziz c grochv or lizersure survey, menticn it rerel

The majority of the calibration customers' concerns are directed not to the technical details of the calibration service but to the timely delivery of that service. It is therefore proper that the calibration services be closely managed. For a Grouo or Division with a large calibration load, this can be a difficult task. The Applied Electrical Measurements Group of the Electrosystems Division has developed microcomputer-based software to provide considerable assistance to the calibration manager. With this database software, complete information on the status of all the calioration joos is instantly available.

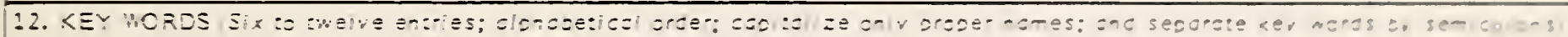
calibration management; calibrations; database management; microcomouter; softiware

13. $\dot{A V A I L A B I L T Y}$

- Unlimizez

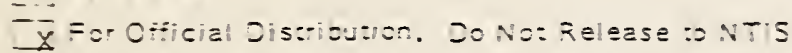

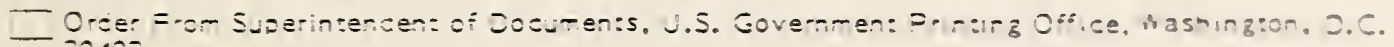

- 20022.

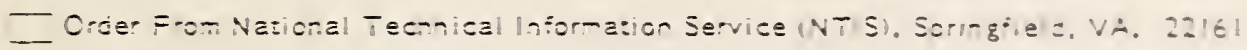

:4. 10. OF DRIPTED PACES

:5. P. ce 



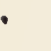


